Research Article

\title{
Biochar Derived from Domestic Sewage Sludge: Influence of Temperature Pyrolysis on Biochars' Chemical Properties and Phytotoxicity
}

\author{
Rahma Inès Zoghlami iD, ${ }^{1}$ Sarra Hechmi, ${ }^{2}$ Rihab Weghlani, ${ }^{1}$ Naceur Jedidi, \\ and Mohamed Moussa ${ }^{1}$ \\ ${ }^{1}$ Arid Region Institute, Eremology and Fight Against Desertification Laboratory (LR016IRA01), University of Gabes, \\ Medenine 4119, Tunisia \\ ${ }^{2}$ Water Research and Technology Center, University of Carthage, P.O. Box 273, Soliman 8020, Tunisia \\ Correspondence should be addressed to Rahma Inès Zoghlami; inesrahma.zoghlami@gmail.com
}

Received 11 June 2021; Revised 9 August 2021; Accepted 3 September 2021; Published 17 September 2021

Academic Editor: Marco Carnevale Miino

Copyright ( 2021 Rahma Inès Zoghlami et al. This is an open access article distributed under the Creative Commons Attribution License, which permits unrestricted use, distribution, and reproduction in any medium, provided the original work is properly cited.

\begin{abstract}
The pyrolytic conversion of domestic sewage sludge (SS) into biochar is a promising method to reduce its large volume and recycle its high-value fuel gas as renewable energy and the use of its chemicals as soil fertilizers. Even though the effects of pyrolysis temperature on energy recovery have been extensively studied, little information has been found on nutrient recovery and biochar's phytotoxicity before its reuse as a soil amendment. This study aims to investigate the ideal pyrolysis temperature that guarantees higher fertility levels as well as meeting quality standards for land disposal. Accordingly, air-dried domestic sewage sludge has been pyrolyzed at $260^{\circ} \mathrm{C}$ (PSS1), at $420^{\circ} \mathrm{C}$ (PSS2), and at $610^{\circ} \mathrm{C}$ (PSS3) with a residence time of 20, 40 , and 60 minutes, respectively. The raw sewage sludge and the produced biochars have been analyzed to determine their volatile organic matter (VOM), mineral content (MC), nutrients' level (total nitrogen TN, available phosphorus $\mathrm{P}$, and potassium $\mathrm{K}$ ), alkalinity ( $\mathrm{pH}$ ), and salinity (electrical conductivity EC and $\mathrm{Na}$ ). The toxic effect of biochars derived from SS has been evaluated through the analysis of trace metals $(\mathrm{Pb}, \mathrm{Cr}, \mathrm{Cd}, \mathrm{Cu}$, and $\mathrm{Zn}$ ) and their toxicity by measuring root elongation inhibition (REI). As expected, pyrolysis temperature has a significant impact on the biochars' characteristics. This has been justified by higher VOM, TN, and P in the sewage sludge (SS) and the biochar (PSS1) produced at low temperature $\left(260^{\circ} \mathrm{C}\right)$. However, higher $\mathrm{pH}, \mathrm{EC}$, $\mathrm{Na}$, and $\mathrm{K}$ have been found in the biochars (PSS2 and PSS3) produced at higher temperature (420 and $610^{\circ} \mathrm{C}$ ). The effect of pyrolysis temperature on trace metals concentrations has shown different patterns from one element to another, which indicates lower levels in the biochar (PSS2) produced at $420^{\circ} \mathrm{C}$. As a result, the lowest REI has been observed in PSS2 compared to that in SS, PSS1, and PSS3, which highlights that $420^{\circ} \mathrm{C}$ is the ideal pyrolysis temperature for the safe reuse of SS as a soil amendment.
\end{abstract}

\section{Introduction}

The US Environmental Protection Agency [1] defines domestic sewage sludge (SS) as a byproduct generated from the wastewater treatment process and refers to them as biosolids [2]. The production of domestic sewage sludge increases with population growth, urbanization, rapid industrialization, and changes in consumption [3]. SS is a potential source of valuable resources and energy $[3,4]$. Since sludge has high organic matter content and is rich in nutrients [5, 6], it can be used as a fertilizer/soil amendment for vegetable crops, horticultural plants, and forests [7]. Once applied to the soil, SS can improve soil fertility level $[6,8,9]$ and enhance plant growth [10], particularly in arid and semiarid regions. SS may also contain potential toxic elements including salts $[6,11]$, trace metals [12], organic pollutants [13], and pathogenic organisms [14]. If it is not managed properly, it can negatively impact human health and the environment $[1,3,15]$. 
Pyrolysis is a thermochemical reaction carried out at elevated temperature $\left(500-1000^{\circ} \mathrm{C}\right)$ and in an inert atmosphere. Depending on the operational conditions, pyrolysis can be aimed at obtaining liquid (bio-oil), gas (hydrogen), or solid (biochar) [16]. Biochar's characteristics are highly dependent on the pyrolysis process conditions [17, 18]. Temperature is one of the most important parameters of the pyrolysis process that can significantly affect the chemical and physical properties of the biochar $[19,20]$ in terms of pore size distribution, functional groups, elementary composition, and the $\mathrm{pH}$ value [21]. At low temperature $\left(200-400^{\circ} \mathrm{C}\right)$, the biochar yields a greater recovery of $\mathrm{C}$ and other nutrients (feedstock dependent), which are usually lost at higher temperature. Higher pyrolysis temperature results in an increase of surface area, carbonized fractions, $\mathrm{pH}$, and volatile matter. Residence time is another important factor that affects the characteristics and production costs of the biochar [22]. Short residence time (of few minutes) can lead to incomplete charring of the raw material, which reduces the stability of the biochar, and the potential of carbon sequestration [23]. It is the most efficient method to produce biofuels for heat and energy generation [24]. Longer residence time (from 20 minutes to few hours) is instrumental for the biochar production with a typical yield of $35 \%$ of dry biomass weight [25]. Recent studies have shown the volatilization of some trace metals (i.e., $\mathrm{Cd}$ and $\mathrm{Zn}$ ) after 30 minutes of residence time and the immobilization of $\mathrm{Cu}, \mathrm{Cr}$, $\mathrm{Ni}$, and $\mathrm{Pb}$ in the biochar after 60 minutes of residence time [26].

Sewage sludge pyrolysis can be used as an effective lowcost technology to reduce its large volume $[27,28]$ and simultaneously recover its valuable byproducts [29]. The thermal decomposition of SS has been investigated since the 1980s for different purposes. Urban and Antal [30], Gonzalo [31], and Thipkhunthod et al. [32] have studied the kinetics of this thermotical reaction and the composition of the noncondensable gases. Others have focused on the effect of pyrolysis conditions (temperature, residence time) on the yield and the properties of the obtained liquid [33, 34, 35]. Sewage sludge pyrolysis has been also investigated to obtain a solid adsorbent (biochar) that can be used for water treatment and pollutant immobilization [36, 37].

Recently, it was demonstrated that SS pyrolysis can cause the thermal breakdown of pathogens and some toxic organic compounds [38, 39], required for possible land application [40,41]. Consequently, biochar derived from SS can have a significant impact on the physical, chemical, and biological properties of depleted soils without posing a risk of contamination [42, 43]. As it is known, most of the studies have focused on the yield rate, the elemental composition $(\mathrm{C}, \mathrm{H}, \mathrm{O}, \mathrm{N})$, the mineral content (ash), the $\mathrm{pH}$, the specific surface area, and metal content [44-47]. However, the effects of pyrolysis temperature on the nutrient status (total $\mathrm{C}$ and $\mathrm{N}$ and available $\mathrm{P}$ and $\mathrm{K}$ ) and the salinity level (EC, $\mathrm{Na}$ ) of the resulting biochar are scarce. The evaluation of the biochar toxicity is also extremely important for screening the suitability of the biochar before its land application. A series of ecotoxicological assays, using selected organisms, can be assessed to determine lethal and sublethal effects of complex materials like biochars [48]. The assessment of root elongation inhibition is one of the most sensitive ecological parameters used to monitor the response of plant seeds exposed to potential pollution [48-50]. The use of lettuce seeds has been recommended thanks to their rapid germination and sensitivity to low concentrations of phytotoxic substances $[49,51]$. Previous studies have reported the use of eucalyptus (Eucalyptus grandis L.) [52] and wheat (Triticum aestivum) [53], whereas the use of lettuce seeds, which is the most sensitive plant, has not been highlighted. Thus, this study may be the first to focus on this point. The objective of this work is to determine the effects of pyrolysis temperature $\left(260,420\right.$, and $\left.610^{\circ} \mathrm{C}\right)$ on the characteristics of an air-dried sewage sludge collected from an urban wastewater treatment plant. The focus of this study is on the produced biochars that will be used as a soil amendment. The change in the nutrient status, salinity level, metal content under the selected temperatures of pyrolysis is investigated, taking into account biochar toxicity using lettuce seeds.

\section{Materials and Methods}

2.1. Sewage Sludge Collection and Biochar Preparation. The domestic sewage sludge has been obtained from a municipal (mechanical-biological) wastewater treatment plant (WTTP) located in Medenine (South-eastern, Tunisia) $\left(33^{\circ} 21^{\prime} 17^{\prime \prime} \mathrm{N} 010^{\circ} 30^{\prime} 19^{\prime \prime} \mathrm{E}\right)$. SS has been generated by an activated sludge treatment process followed by dewatering using drying beds. Three samples of sewage sludge were randomly collected from the surface bed during winter 2019 and then homogenized into a composite sample according to Lacorte et al. [54]. In the laboratory, SS pyrolysis has been assessed in a furnace (Nabertherm), where $500 \mathrm{ml}$ of nitrogen has been added at every pyrolysis process to maintain an anoxic environment as recommended by Mohammed et al. [55] and Ye et al. [56]. SS has been pyrolyzed at $260^{\circ} \mathrm{C}$ (PSS1), $420^{\circ} \mathrm{C}$ (PSS2), and $610^{\circ} \mathrm{C}$ (PSS3) for 20, 40, and 60 minutes, respectively, with a heating rate of $10^{\circ} \mathrm{C} \cdot \mathrm{min}^{-1}$. The raw SS has been used as a control, and all treatments have been performed in five replicates. After pyrolysis, SS samples (raw and biochars) were cooled down to room temperature, passed through a $2 \mathrm{~mm}$ mesh sieve, and stored before analysis [54].

2.2. Physical and Chemical Characterization of the Raw Sewage Sludge and the Produced Biochars. The $\mathrm{pH}$ and electrical conductivity (EC) have been determined in sample-water extracts at a ratio of $1: 5$ and $1: 2.5$, respectively, after shaking for 2 hours.

The volatile organic matter (VOM) has been calculated based on the air-dried weight according to the following equation:

$$
\operatorname{VOM}(\%)=100-\mathrm{MC} \text {, }
$$

where $\mathrm{MC}$ is the mineral content determined according to Yong et al. [57]. Firstly, air-dried samples have been weighed 
and then combusted in a furnace at $560^{\circ} \mathrm{C}$ for 6 hours. The final weight has been recorded using the same calibrated analytical balance. MC has been calculated using the following equation:

$$
\mathrm{MC}(\%)=\frac{m_{2}}{m_{1}} \times 100,
$$

where $m_{1}$ and $m_{2}$ are the weight of the air-dried and the combusted sample, respectively.

Total nitrogen (TN) has been determined according to the Kjeldahl method [58]. Available phosphorus "orthophosphate" (P) has been determined by the colorimetric method at $430 \mathrm{~nm}$ according to ISO [59]. Exchangeable bases $\left(\mathrm{Na}^{+}\right.$and $\left.\mathrm{K}^{+}\right)$have been extracted from the biochar with $\mathrm{HCl}(6 \mathrm{~N})$ and measured by atomic adsorption [60]. Trace metals $(\mathrm{Cu}, \mathrm{Cd}, \mathrm{Zn}, \mathrm{Pb}$, and $\mathrm{Cr}$ ) were determined by mixing $0.5 \mathrm{~g}$ of samples with $\mathrm{HCI}$ and $\mathrm{HNO}_{3}$ (5 ml each) [61]. After acid digestion, the mixtures have been filtered and measured using atomic absorption spectrometry (AAS) equipped with a graphite oven (Perkin Elmer Instruments, USA).

2.3. Phytotoxicity Test. The phytotoxicity assay has been done in Petri dishes of $15 \mathrm{~mm}$ diameter using lettuce seeds (Lactuca sativa L.). Sample solutions have been prepared by dissolving 1 gram of the sample in $100 \mathrm{ml}$ of distilled water and then filtered before their use. After that, filter papers (Whatman no. 3) have been placed in Petri dishes and humidified with $9 \mathrm{ml}$ of the prepared sample solution. $9 \mathrm{ml}$ of distilled water has been used as control. Subsequently, 20 lettuce seeds have been placed on top of the paper filter. Petri dishes have been covered and incubated in the dark at $25^{\circ} \mathrm{C}$ for 7 days. At the end of the incubation period, germinated plantlets have been meticulously uprooted and the numbers of germinated seeds have been counted and the lengths of the roots have been measured [48]. To provide an integrative interpretation of the measurements, seed germination and root elongation have been combined into the root elongation inhibition (REI) as shown in the following equation:

$$
\operatorname{REI}(\%)=(1-\operatorname{Ig}) \times 100,
$$

where Ig is the index of germination calculated according to the following equation:

$$
\operatorname{Ig}=\frac{\left(G_{S} \times L_{S}\right)}{\left(G_{C} \times L_{C}\right)},
$$

where $\mathrm{Gn}$ and $\mathrm{Ln}$ are, respectively, the mean number of germinated seeds and root length in the sample solution and Gc and Lc are the mean values in the control.

2.4. Statistical Analysis. Data has been analyzed by ANOVA with post hoc Duncan's multiple range test at $P \leq 0.05$ for mean values' separation to highlight the effect of pyrolysis temperature of sewage sludge on chemical proprieties and phytotoxicity (STATISTICA 5.0, StatSoft Inc., Tulsa, USA). The differences between mean values have been annotated with alphabetical letters ( $a, b, c, \ldots)$ where " $a$ " is significantly different from " $b$ " and " $b$ " from "c." Mean values annotated with the same letter are not statistically different. A Pearson product-moment correlation matrix $(P \leq 0.05)$ is constructed to determine the strength of the relationship $(r)$ between the measured parameters in each sample.

\section{Results and Discussion}

3.1. Effect of Pyrolysis Temperature on the Chemicals' Recovery. The increase of pyrolysis temperature has a significant effect on the variation of physicochemical properties of the sewage sludge (Table 1).

With the increase of pyrolysis temperature, the content of volatile organic matter (VOM) in the produced biochars drops from $30.9\left(260^{\circ} \mathrm{C}\right)$ to $14.2\left(420^{\circ} \mathrm{C}\right)$ and $11 \%\left(610^{\circ} \mathrm{C}\right)$ compared to the raw SS (39.4\%). Tomczyk et al. [62] explained that, at temperatures below $450^{\circ} \mathrm{C}$, low-molecular-weight polymers are easily decomposed, while high-molecularweight polymers are very resistant to thermal degradation. The decrease of volatile matters reflects the formation of recalcitrant compounds and the increase of stable carbon resistant to $\mathrm{CO}_{2}$ volatilization [63]. In this regard, biochar carbon sequestration lasts longer; therefore, its production and land application may help mitigate climate change [64]. Moreover, the decomposition of labile organic matter, during pyrolysis, creates more pores [65] and increases the surface area of the biochars. The amendment of such biochars can help retain nutrients required for plant growth and prevent water runoff [66]. Substantial decreases are noticed for TN with the increase of temperature as follows: SS $>\operatorname{PSS} 1\left(260^{\circ} \mathrm{C}\right)$ $>$ PSS $2\left(420^{\circ} \mathrm{C}\right)>\operatorname{PSS} 3\left(610^{\circ} \mathrm{C}\right)$. For instance, TN decreases by $48.7,67.6$, and $89.2 \%$ after pyrolysis at 260,420 , and $610^{\circ} \mathrm{C}$, respectively. Ye et al. [56] also reported the decrease of nitrogen in the biochar with the increase of pyrolysis temperature. The nitrogen element starts to volatilize at low temperatures (approximately $200^{\circ} \mathrm{C}$ ) due to the cleavage and break of weak bonds within the biochar structure. Intani et al. [39] and Saffari et al. [67] showed that large amounts of $\mathrm{N}$ are lost as $\mathrm{N}_{2} \mathrm{O}, \mathrm{NO}$, and $\mathrm{NO}_{2}$. As pyrolysis temperature increases (above $300^{\circ} \mathrm{C}$ ), the nitrogen is transformed into a heterocyclic aromatic form with more stable structures (i.e., pyridine, pyrrole, and quaternary nitrogen) [68]. In this regard, the land application of biochars produced at higher temperatures can reduce the volatilization of $\mathrm{NH}_{3}$ [56], $\mathrm{N}_{2} \mathrm{O}$ emissions [68], and nitrogen leaching [69]. The $\mathrm{C} / \mathrm{N}$ ratio is generally used as a good indicator of the status of nutrients during mineralization [70]. It reflects the capacity of organic substrates to release inorganic $\mathrm{N}$ when incorporated into soils. The variation of $\mathrm{C} /$ $\mathrm{N}$ depends on the total organic carbon (TOC) and total nitrogen (TN). According to this study, biochars have relatively lower levels of total nitrogen (TN). However, their very high TOC amount makes the $\mathrm{C} / \mathrm{N}$ ratios fairly high (Table 1 ), indicating a net microbial immobilization. The significant decrease of $\mathrm{C} / \mathrm{N}$ with the increase of pyrolytic temperatures from $260^{\circ} \mathrm{C}$ (PSS1) to $420^{\circ} \mathrm{C}$ (PSS2) and to $610^{\circ} \mathrm{C}$ (PSS3) is mainly attributed to organic $\mathrm{C}$ sequestration reflected by the loss of VOM (Table 1), as previously reported by Wei et al. 
[71]. Accordingly, biochars with higher C/N (PSS1 and PSS2) may be useful as soil amendments by encouraging microbial immobilization [70] and slowing the mineralization rate [71].

Phosphorus $(\mathrm{P})$ is the second most important nutrient after nitrogen for plant growth [42]. In this study, the available $\mathrm{P}$ follows the same trend as $\mathrm{TN}$, showing lower concentrations in the biochars produced at 420 and $610^{\circ} \mathrm{C}$ $\left(0.12 \mathrm{mg} \mathrm{kg}^{-1}\right)$ in comparison to the raw SS $\left(0.014 \mathrm{mg}^{\bullet} \mathrm{kg}^{-1}\right)$. Nevertheless, these concentrations are considered far below the range of desirable available $\mathrm{P}$ content $(0.2$ and $50 \mathrm{mg}^{\bullet} \mathrm{kg}^{-1}$ ) recommended for plant growth [72]. According to Novak et al. [73], P volatilization starts at $700^{\circ} \mathrm{C}$, suggesting that available $\mathrm{P}$ in the biochars has changed to unavailable forms. This is consistent with the results of Qian and Jiang [74], reporting a significant reduction of P solubility in biochars compared to that in the raw material (SS). Dai et al. [75] explained that, under the pyrolysis process, organic $\mathrm{P}$ is transformed into insoluble phosphate (e.g., $\mathrm{FePO}_{4}, \mathrm{AlPO}_{4}, \mathrm{CaPO}_{4}$, and $\mathrm{MgPO}_{4}$ ) [74-76], thus limiting the risk of $\mathrm{P}$ loss through runoff or leaching. As mineral $\mathrm{P}$ resources decrease, biochar can play an important role to recycle $\mathrm{P}$ from wastes like domestic sewage sludge [21, 77]. In the soil, $\mathrm{P}$ solubility is mainly regulated by the interaction of $\mathrm{P}$ with $\mathrm{Ca}^{2+}, \mathrm{Mg}^{2+}, \mathrm{Al}^{3+}$, and $\mathrm{Fe}^{2+} / \mathrm{Fe}^{3+}$ by forming Ca$\mathrm{Mg}-\mathrm{Al}$ or Fe-phosphates. Once the biochar is applied to acid soil, the $\mathrm{pH}$ of the soil increases, and the amount of adsorbed $P$ decreases [78] and becomes more available. This was recently confirmed by Glaser and Lehr [77] showing that the addition of biochar can significantly increase the availability of phosphorus in agricultural soils by $460 \%$.

In this study, the mineral content (MC) increases along with pyrolysis temperature, which highlights the highest percentages in the biochars produced at $420^{\circ} \mathrm{C}$ (PSS2: 85.5\%) and $610^{\circ} \mathrm{C}$ (PSS3: 89\%) (Table 1). The mineral content corresponds to the remaining noncombustible component referred to as ash [46, 47, 79]. Zielińska et al. [80] also showed that sewage sludge-derived biochars are characterized by high ash content (64.1-79.1\%). According to Yang et al. [64], biochars, with high mineral content, have higher CEC. This can be attributed to the formation of O-containing surface functional groups including alkali salts, alkali trace metals, and polycyclic aromatic hydrocarbons (PAHs) $[44,63]$. The greater the degree of formation of aromatic structures is, the higher the resistance of the biochar to microbial degradation will be [62]. The concentration of these nonpyrolyzed inorganic elements can increase the $\mathrm{pH}$ value of the biochar and affect soil chemistry (e.g., soil $\mathrm{pH}$, nutrient availability, and metal toxicity) [81]. As expected, $\mathrm{pH}$ increases synchronically with pyrolysis temperature reaching 7.8 (at $420^{\circ} \mathrm{C}$ ) and 9.11 (at $610^{\circ} \mathrm{C}$ ) in comparison with the raw feedstock (6.74) (Table 1). However, at low pyrolysis temperature $\left(260^{\circ} \mathrm{C}\right), \mathrm{pH}$ decreases slightly but significantly in PSS1, showing the lowest $\mathrm{pH}$ among all the samples (6.35). Higher $\mathrm{pH}$ values in the biochars PSS2 and PSS3 are the result of the accumulation of alkali salts (i.e., $\mathrm{Na}, \mathrm{K}, \mathrm{Ca}$, and $\mathrm{Mg}$ ). In this study, both $\mathrm{Na}$ and $\mathrm{K}$ increase simultaneously with the increase of pyrolysis temperature. As such, $\mathrm{K}$ increases by $32,46.38$, and $46.36 \%$, respectively, for PSS1, PSS2, and PSS3, and Na increases by 25, 34.7, and
$35 \%$ respectively (Table 1 ). Therefore, $\mathrm{Na}$ and $\mathrm{K}$ show greater concentrations in the biochars (PSS2 and PSS3) with the highest $\mathrm{pH}$ (7.8 and 9.11, respectively), which confirms the interrelation between alkali salts and $\mathrm{pH}(r=0.5$ for $\mathrm{Na}$; $r=0.65$ for K) (Table 2).

Same observations were made by $\mathrm{Yu}$ et al. [82], explaining that, above $300^{\circ} \mathrm{C}$, alkali salts begin to separate from the organic matrix and increase the $\mathrm{pH}$ of the product. The $\mathrm{pH}$ becomes constant at a temperature around $600^{\circ} \mathrm{C}$ while all the alkali salts are released from the pyrolytic structure [83]. Around $200-300^{\circ} \mathrm{C}$, cellulose and hemicelluloses decompose and yield organic acids and phenolic substances that lower the $\mathrm{pH}$ of the products [82]. In addition to $\mathrm{pH}, \mathrm{EC}$ also increase in the biochars (PSS2 and PSS3) produced at 420 and $610^{\circ} \mathrm{C}$, reaching, respectively, 4.4 and $4.55 \mathrm{mS} \cdot \mathrm{cm}^{-1}$ with respect to the control $\left(3.09 \mathrm{mS} \cdot \mathrm{cm}^{-1}\right)$ (Table 1). Increases in EC are the result of the accumulation of chemical compounds responsible which determines the salinity increase (i.e., $\mathrm{Na}, \mathrm{K}, \mathrm{Ca}$, and $\mathrm{Mg}$ ) $[78,84]$. This is justified by positive and significant correlations between EC and $\mathrm{Na}(r=0.73)$ and $\mathrm{K}(r=0.87)$ (Table 2). For alkaline soils (such as the majority of arid soils), it is important to select properly the raw materials and optimized pyrolysis temperature to produce the aimed biochars that prevent both soil salinization and sodicity. Overall, EC values are below the threshold required for plant growth, root development, and soil biological activity [85-87]. Nonetheless, biochar application on-field should be monitored particularly in arid soils characterized by dry spell which accentuates salt accumulation within the soil surface that leads to soil salinization $[9,11]$.

3.2. Effect of Pyrolysis Temperature on Trace Metal Concentration and Biochar Toxicity. The reuse of domestic sewage sludge has been proposed as a reliable and effective approach for soil fertility recovery because they enhance soil organic $C$ storage [88] and enable valuable components to be recycled (e.g., N, P, and K) [89]. Nonetheless, sewage sludge can be highly contaminated with phytotoxic trace metals (i.e., Cr, $\mathrm{Cd}, \mathrm{Cu}, \mathrm{Pb}$, and $\mathrm{Zn})[12,45]$ and pathogens $[14]$ as well as toxic organic substances such as polyaromatic hydrocarbons, chlorobenzene, and plasticizers [38, 39]. Hence, they cannot be directly applied in farmland according to the EUlegislation directives (EU) [14]. As confirmed by recent studies, one of the main characteristics of the pyrolysis process is the sanitization of the sludge's pathogens and the destruction of organic compounds [14]. The presence of metals in the biochar is likely dependent on the origin of the feedstock or on pyrolysis conditions that may promote their accumulation in the biochar or their volatilization $[44,90,91]$. In this study, trace metals $(\mathrm{Cu}, \mathrm{Cd}, \mathrm{Zn}, \mathrm{Pb}$, and $\mathrm{Cr}$ ), initially present in the raw SS, remain concentrated in the biochars (Figure 1).

As shown in Figure 1, the contents of trace metals in the sewage sludge vary significantly in the following order $\mathrm{Zn}>\mathrm{Cu}>\mathrm{Cr}>\mathrm{Pb}>\mathrm{Cd}$, where $\mathrm{Zn}$ reaches $3 \mathrm{ppm}$ whereas the content of $\mathrm{Cd}$ is only $0.027 \mathrm{ppm}$. The same trend was reported in the findings of Mancinelli et al. [91], as $\mathrm{Zn}$ is the 
TABLE 1: Changes in the physicochemical properties of the sewage sludge and biochar samples obtained at different pyrolysis temperatures.

\begin{tabular}{|c|c|c|c|c|}
\hline Parameters & SS & PSS1 & PSS2 & PSS3 \\
\hline $\mathrm{pH}$ & $6.74^{\mathrm{b}} \pm 0.07$ & $6.35^{\mathrm{a}} \pm 0.02$ & $7.8^{c} \pm 0.03$ & $9.11^{\mathrm{d}} \pm 0.15$ \\
\hline $\mathrm{EC}\left(\mathrm{mS} \mathrm{cm}^{-1}\right)$ & $3.09^{\mathrm{a}} \pm 0.23$ & $4.32^{\mathrm{b}} \pm 0.122$ & $4.40^{\mathrm{b}} \pm 0.31$ & $4.55^{\mathrm{b}} \pm 0.36$ \\
\hline $\mathrm{MC}(\%)$ & 60.6 & 69.1 & 85.8 & 89 \\
\hline VOM (\%) & $39.4^{\mathrm{b}} \pm 11.6$ & $30.9^{\mathrm{b}} \pm 4.82$ & $14.2^{\mathrm{a}} \pm 3.1$ & $11^{\mathrm{a}} \pm 0.37$ \\
\hline TOC (\%) & 22.9 & 17.9 & 8.22 & 6.39 \\
\hline $\mathrm{TN}(\%)$ & $0.037^{\mathrm{c}} \pm 0.01$ & $0.019^{\mathrm{b}} \pm 0.001$ & $0.012^{\mathrm{a}} \pm 0.004$ & $0.07^{\mathrm{a}} \pm 0.002$ \\
\hline $\mathrm{C} / \mathrm{N}$ & $618.9^{\mathrm{b}}$ & $942.1^{\mathrm{c}}$ & $685^{\mathrm{b}}$ & $91.3^{\mathrm{a}}$ \\
\hline $\mathrm{P}\left(\mathrm{mg} \mathrm{kg}^{-1}\right)$ & $0.014^{\mathrm{c}}$ & $0.013^{\mathrm{b}}$ & $0.012^{\mathrm{a}}$ & $0.012^{\mathrm{a}}$ \\
\hline $\mathrm{K}\left(\mathrm{mg} \mathrm{kg}^{-1}\right)$ & $26.3^{\mathrm{a}} \pm 5.25$ & $38.7^{\mathrm{b}} \pm 7.74$ & $49^{\mathrm{b}} \pm 0.26$ & $48.9^{\mathrm{b}} \pm 8.32$ \\
\hline $\mathrm{Na}\left(\mathrm{mg} \mathrm{kg}{ }^{-1}\right)$ & $33.6^{\mathrm{a}} \pm 8.17$ & $44.9^{\mathrm{ab}} \pm 10.2$ & $51.1^{\mathrm{b}} \pm 5.48$ & $51.5^{\mathrm{b}} \pm 9.33$ \\
\hline
\end{tabular}

SS: untreated sewage sludge (control), PSS1, PSS2, and PSS3: sewage sludge pyrolyzed at, respectively, 260, 420, and $610^{\circ} \mathrm{C}$. Values are the average of five replicates, \pm : standard deviation. For each parameter, sample mean values with the same letters are not statistically different at $P \leq 0.05$.

TABLE 2: Pearson product-moment correlation coefficients $(r)$ of sewage sludge parameters.

\begin{tabular}{|c|c|c|c|c|c|c|c|c|c|c|c|c|c|}
\hline & $\mathrm{pH}$ & EC & TN & $\mathrm{P}$ & VOM & $\mathrm{Cu}$ & $\mathrm{Zn}$ & $\mathrm{Cd}$ & $\mathrm{Pb}$ & $\mathrm{Cr}$ & $\mathrm{Na}^{+}$ & $\mathrm{K}^{+}$ & REI \\
\hline $\mathrm{pH}$ & - & 0.52 & $-0.68^{*}$ & $-0.81^{* *}$ & $-0.80^{* *}$ & 0.10 & $-0.68^{*}$ & 0.07 & -0.15 & -0.47 & 0.50 & $0.65^{*}$ & -0.12 \\
\hline EC & & - & $-0.88^{* *}$ & $-0.85^{* *}$ & $-0.76^{* *}$ & -0.31 & $-0.81^{* *}$ & -0.23 & -0.25 & -0.49 & $0.73^{* *}$ & $0.87^{* *}$ & -0.39 \\
\hline $\mathrm{TN}$ & & & - & $0.91^{* *}$ & $0.89^{* *}$ & 0.36 & $0.84^{* *}$ & 0.21 & 0.42 & 0.42 & $-0.79^{* *}$ & $-0.87^{* *}$ & 0.37 \\
\hline $\mathrm{P}$ & & & & - & $0.91^{* *}$ & 0.32 & $0.91^{* *}$ & 0.28 & 0.47 & 0.41 & $-0.78^{* *}$ & $-0.91^{* *}$ & 0.42 \\
\hline VOM & & & & & - & 0.28 & $0.72^{* *}$ & 0.36 & 0.38 & 0.36 & $-0.79^{* *}$ & $-0.89^{* *}$ & 0.38 \\
\hline $\mathrm{Cu}$ & & & & & & - & 0.39 & $0.79^{* *}$ & $0.62^{*}$ & -0.51 & -0.44 & -0.45 & 0.49 \\
\hline $\mathrm{Zn}$ & & & & & & & - & 0.16 & 0.54 & 0.22 & $-0.63^{*}$ & $-0.78^{* *}$ & 0.48 \\
\hline $\mathrm{Cd}$ & & & & & & & & - & 0.51 & -0.36 & -0.47 & -0.45 & 0.27 \\
\hline $\mathrm{Pb}$ & & & & & & & & & - & -0.21 & -0.41 & -0.36 & 0.35 \\
\hline $\mathrm{Cr}$ & & & & & & & & & & - & -0.31 & -0.34 & -0.39 \\
\hline $\mathrm{Na}^{+}$ & & & & & & & & & & & - & $0.935^{* *}$ & -0.30 \\
\hline $\mathrm{K}^{+}$ & & & & & & & & & & & & - & -0.40 \\
\hline IER & & & & & & & & & & & & & - \\
\hline
\end{tabular}

VOM: volatile organic matter; REI: root elongation inhibition; ${ }^{*} P \leq 0.05 ;{ }^{* *} P \leq 0.01$.

element with the highest concentrations followed by $\mathrm{Cu}$, and $\mathrm{Cd}$ is the trace metal with the lowest concentrations in the feedstock and the biochars. Previously, Yuan et al. [21] explained that $\mathrm{Cd}$ tends to volatilize during pyrolysis and the other trace metals initially present in the feedstock generally remain and become concentrated in the biochar. Unexpectedly, trace metals ( $\mathrm{Zn}, \mathrm{Cu}, \mathrm{P}, \mathrm{Cd}$, and $\mathrm{Cr}$ ) concentrations in the biochars (PSS1, PSS2, and PSS3) are not significantly different from those in the raw feedstock (SS). The total concentration of $\mathrm{Zn}$ decreases significantly in the biochars PSS2 and PSS3 with the increase of pyrolysis temperature. On the other hand, $\mathrm{Cu}, \mathrm{Pb}$, and $\mathrm{Cd}$ concentrations decrease significantly in the biochars (PSS1 and PSS2) and increase in PSS3, with no significant variations compared to the raw feedstock (SS). As for $\mathrm{Cr}$, the concentrations significantly decrease in PSS $1\left(260^{\circ} \mathrm{C}\right)$ and PSS3 $\left(610^{\circ} \mathrm{C}\right)$ and increase in PSS2 $\left(420^{\circ} \mathrm{C}\right)$. These results are different from the previous ones [61, 91, 92], which emphasize the increase of trace metals in the form of oxide and sulfide from 300 to $700^{\circ} \mathrm{C}$. For instance, Méndez et al. [92] found that biochar derived from sewage sludge pyrolyzed at $500^{\circ} \mathrm{C}$ retains $31 \%$ of $\mathrm{Cu}$, $30 \%$ of $\mathrm{Pb}$, and about $28 \%$ of $\mathrm{Ni}, \mathrm{Cd}$, and $\mathrm{Zn}$ compared to the raw feedstock. Similarly, Lu et al. [61] found that biochars produced from sewage sludge pyrolyzed at 300, 400, 500, 600 , and $700^{\circ} \mathrm{C}$ retain $90.4-98.3 \%$ of $\mathrm{Pb}, 96.4-99.5 \%$ of $\mathrm{Zn}$, 92.5-99.3\% of $\mathrm{Ni}, 85.8-98.5 \%$ of $\mathrm{Cd}, 81.5-94.5 \%$ of $\mathrm{Cu}$, and
70.0-87.5\% of Cr. This phenomenon was also observed in other studies during the pyrolysis of other feedstocks $[18,19,25,91]$, attributing trace metal retention to their low volatility [84]. Overall, total concentration of the five trace metals in the biochars (PSS1, PSS2, and PSS3) remains below the regulatory limits set by the European Biochar Certificate [93]. Accordingly, the following maximum values for heavy metals correspond to $40 \mathrm{ppm}$ for $\mathrm{Zn}, 12 \mathrm{ppm}$ for $\mathrm{Pb}, 10 \mathrm{ppm}$ for $\mathrm{Cu}, 8 \mathrm{ppm}$ for $\mathrm{Cr}, 3 \mathrm{ppm}$ for $\mathrm{Ni}$, and $0.1 \mathrm{ppm}$ for $\mathrm{Cd}$. This could be attributed to the low concentrations of trace metals detected in the domestic sewage sludge (SS) (Figure 1).

The effect of pyrolysis temperature on the concentration of trace metals in the biochars was the main focus of research on the production and characterization of biochars [11]. However, the toxicity of the produced biochar is still unclear [41]. In this study, a phytotoxicity test is used as an effective and a low-cost equipment to identify the toxic effects of the produced biochars on root elongation inhibition (REI) of lettuce seeds (Figure 2).

Sewage sludge pyrolysis has a significant effect $(P \leq 0.05)$ on the lettuce growth, showing lower REI in the biochars (PSS1, PSS2, and PSS3) compared to the raw feedstock (SS) (Figure 2). The lowest REI is found in the biochars (PSS1 and PSS2) produced at low temperatures (260 and $420^{\circ} \mathrm{C}$, respectively). This implies that PSS 1 and PSS2 do not cause root elongation inhibition of lettuce 

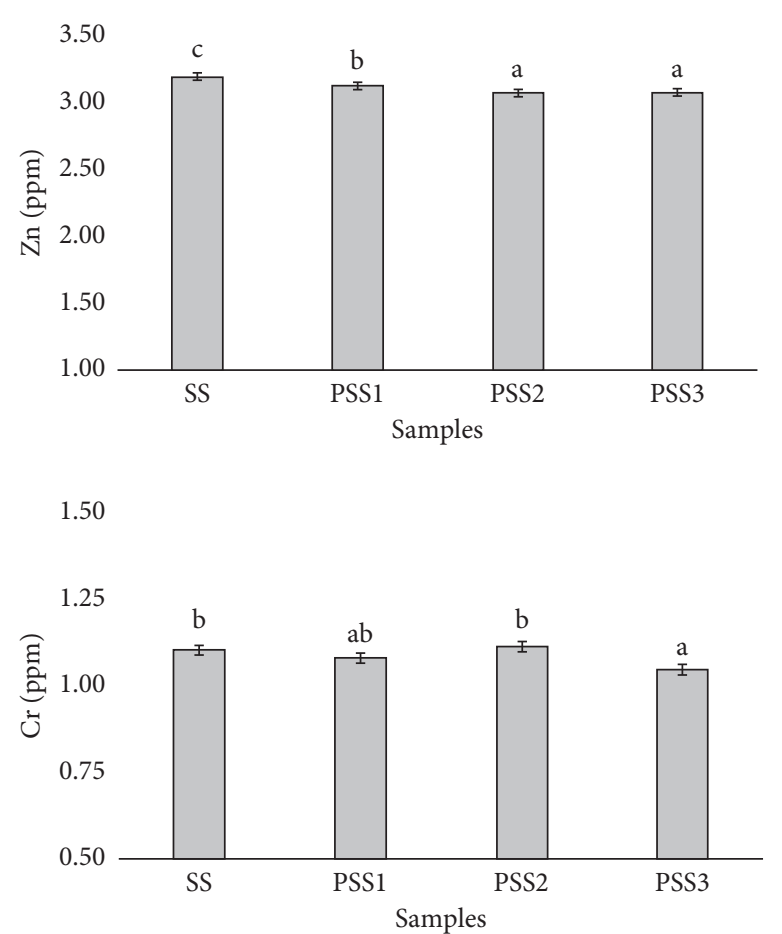

1.50

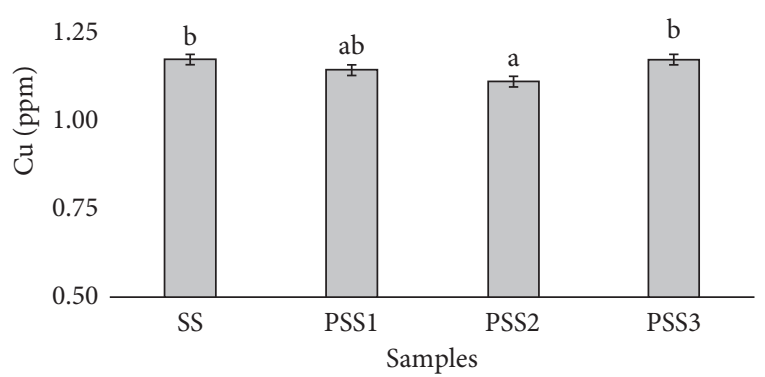

1.50

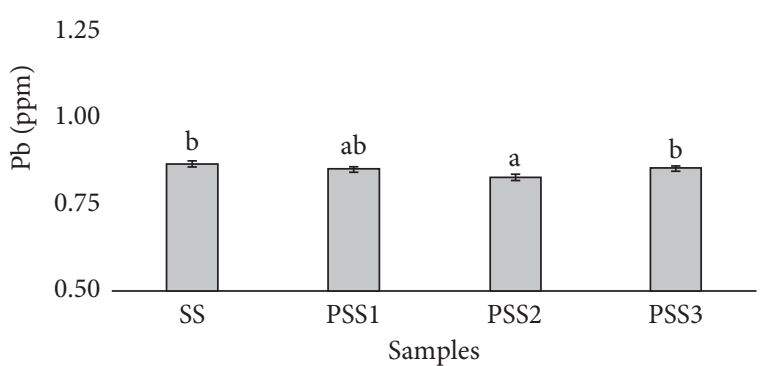

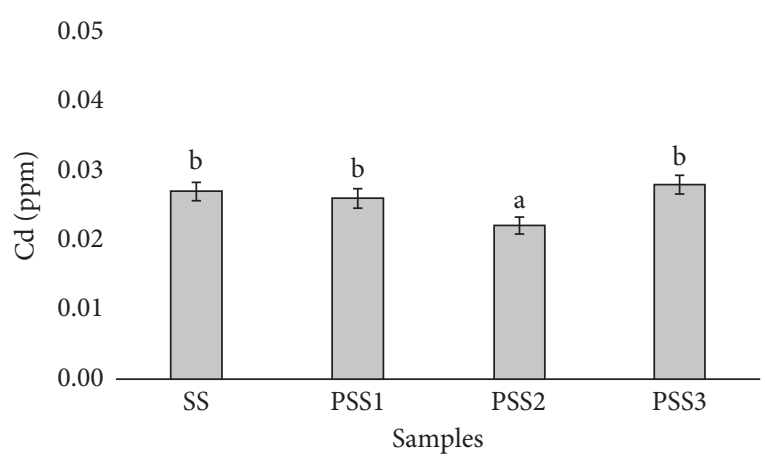

Figure 1: Variation of trace metal (Cu, Cd, $\mathrm{Zn}, \mathrm{Pb}$, and $\mathrm{Cr}$ ) concentrations in the biochars produced at $260^{\circ} \mathrm{C}(\mathrm{PSS} 1), 420^{\circ} \mathrm{C}(\mathrm{PSS} 2)$, and $610^{\circ} \mathrm{C}$ (PSS3) with respect to the raw sewage sludge (SS). For each parameter, sample mean values with the same letters are not statistically different at $P \leq 0.05$.

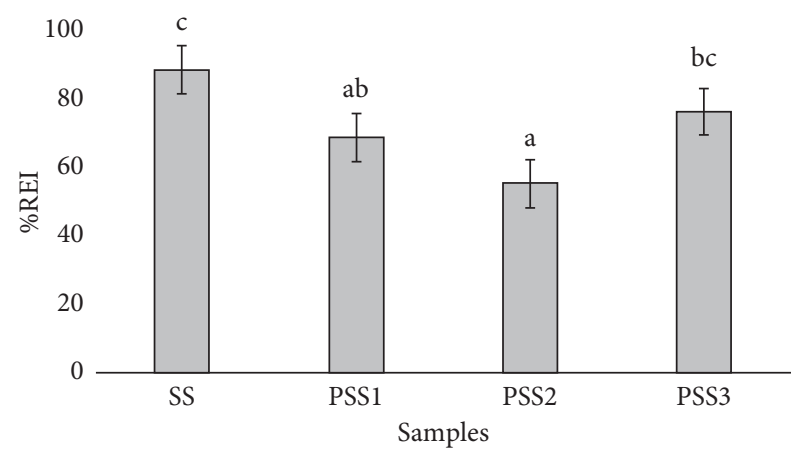

FIGURE 2: Variation of root elongation inhibition of lettuce seeds in the biochars produced at $260^{\circ} \mathrm{C}(\mathrm{PSS} 1), 420^{\circ} \mathrm{C}$ (PSS2), and $610^{\circ} \mathrm{C}$ (PSS3) with respect to the raw sewage sludge (SS). For each parameter, sample mean values with the same letters are not statistically different at $P \leq 0.05$. 
compared to PSS3 and SS. This is in line with the findings of previous researches which have described the significant influence of pyrolysis temperature on biochar toxicity $[39,50]$. Therefore, it may be assumed that the pyrolysis temperature $\left(420^{\circ} \mathrm{C}\right)$ is the most proper option when the purpose of producing biochar is to improve soil quality without causing its toxicity. Our statistical data indicate insignificant correlations between REI and the analyzed trace metals and biochar salinity (EC, Na) (Table 2). This highlights the potential unavailability of trace metals and soluble salts for lettuce uptake and the presence of other elements responsible for the increase of REI. Metal and salt availability are likely to be hindered by the alkalinity nature of the produced biochars, which reflects their immobility (adsorption or precipitation) [40]. Intani et al. [39] reported that free radicals, which are generated during pyrolysis, have more detrimental effects on seed germination, root-shoot elongation, and plant growth than PAHs and trace metals. Thus, further studies are needed regarding free radicals' formation under SS pyrolysis and their contribution to biochar toxicity.

\section{Conclusion}

In this study, sewage sludge is pyrolyzed at ascended temperatures $\left(260,420\right.$, and $\left.610^{\circ} \mathrm{C}\right)$ and compared to the raw material. The agronomic potential of biochars derived from sewage sludge is studied by the macronutrient content (TOC, TN) and the nutrient status ( $\mathrm{P}, \mathrm{K}$, and $\mathrm{MC}$ ). The toxicity of the produced biochars is investigated through total concentrations of trace metals and the index of root elongation inhibition using lettuce seeds. Pyrolysis temperature has a strong influence on biochar's physicochemical properties (e.g., $\mathrm{pH}, \mathrm{EC}, \mathrm{VOM}, \mathrm{Na}$, and $\mathrm{K}$ ) and the transformation of the organic elements $(\mathrm{C}, \mathrm{N}$, and $\mathrm{P})$ into mineral stable forms. This is proved by the increase of mineral content (MC) particularly in the biochars (PSS2 and PSS3) produced at higher temperature $\left(420\right.$ and $\left.610^{\circ} \mathrm{C}\right)$ and subsequently the increase of biochar's $\mathrm{pH}$ and EC. Unexpectedly, biochars have generally lower trace metal concentrations compared to the raw feedstock, especially in the biochar produced at $420^{\circ} \mathrm{C}$ (PSS2). Hence, biochar (PSS2) has a minimum contribution to the root elongation inhibition compared to the other samples. All in all, sewage sludge pyrolysis at $420^{\circ} \mathrm{C}$ (for 40 minutes) is recommended for reuse as a safe soil amendment in arid and semiarid regions. Further studies should investigate the formation of free radicals and confirm their contribution to the biochar toxicity.

\section{Data Availability}

All data used to support the findings of this study are included in the article and will be, in case the article will be accepted, accessible to readers.

\section{Conflicts of Interest}

The authors declare no conflicts of interest.

\section{Acknowledgments}

The authors would like to thank the Foundation for Research Support of the Arid Region Institute of Medenine (IRA) (Khatelli Hussein) and the staff of Eremology and Fight Against Desertification Laboratory (Habib Lamourou, Yosra Suidi, and Houda Oueriemmi) for their help and encouragement. All the authors also thank the University of Gabés and Sfax, for funding this research project.

\section{References}

[1] USEPA, Code of Federal Regulations, Part 503-Standards for the Use or Disposal of Sewage Sludge, https://www. govinfo.gov/content/pkg/CFR-2018-title40-vol32/xml/CFR2018-title40-vol32-part503.xml, 2018.

[2] R. Pöykiö, G. Watkins, and O. Dahl, "Characterisation of municipal sewage sludge as a soil improver and a fertilizer product," Ecological Chemistry and Engineering S, vol. 26, no. 3, pp. 547-557, 2019.

[3] V. Kumar, A. K. Chopra, and A. Kumar, "A review on sewage sludge (Biosolids) a resource for sustainable agriculture," Archives of Agriculture and Environmental Science, vol. 2, no. 4, pp. 340-347, 2017.

[4] M. Gubišová, M. Horník, K. Hrčková et al., "Sewage sludge as a soil amendment for growing biomass plant arundo donax L," Agronomy, vol. 10, no. 5, p. 678, 2020.

[5] A. Christodoulou and K. Stamatelatou, "Overview of legislation on sewage sludge management in developed countries worldwide," Water Science and Technology, vol. 73, no. 3, pp. 453-462, 2015.

[6] R. I. Zoghlami, S. MokniTlili, H. Hamdi, M. N. Khelil, N. Ben Aissa, and N. Jedidi, "Physicochemical, microbiological and ecotoxicological characterization of urban sewage sludge destined for agricultural reuse," Journal of New sciences, vol. 27, pp. 1540-1548, 2016.

[7] M. Usman, P. Faure, C. Ruby, and K. Hanna, "Remediation of $\mathrm{PAH}$-contaminated soils by magnetite catalyzed Fenton-like oxidation," Applied Catalysis B: Environmental, vol. 117-118, pp. 10-17, 2012.

[8] S. Hechmi, H. Hamdi, S. Mokni-Tlili et al., "Carbon mineralization, biological indicators, and phytotoxicity to assess the impact of urban sewage sludge on two light-textured soils in a microcosm," Journal of Environmental Quality, vol. 49, no. 2, pp. 460-471, 2020.

[9] H. Hamdi, S. Hechmi, M. N. Khelil et al., "Repetitive land application of urban sewage sludge: effect of amendment rates and soil texture on fertility and degradation parameters," Catena, vol. 172, pp. 11-20, 2019.

[10] A. Wyrwicka and M. Urbaniak, "The biochemical response of willow plants (Salix viminalis L.) to the use of sewage sludge from various sizes of wastewater treatment plant," The Science of the Total Environment, vol. 615, pp. 882-894, 2018.

[11] S. Hechmi, H. Hamdi, S. Mokni-Tlili et al., "Impact of urban sewage sludge on soil physico-chemical properties and phytotoxicity as influenced by soil texture and reuse conditions," Journal of Environmental Quality, vol. 49, no. 4, pp. 973-986, 2020.

[12] S. Khadhar, A. Sdiri, A. Chekirben, R. Azouzi, and A. Charef, "Integration of sequential extraction, chemical analysis and statistical tools for the availability risk assessment of heavy metals in sludge amended soils," Environmental Pollution, vol. 263, Article ID 114543, 2020. 
[13] X.-Z. Meng, A. K. Venkatesan, Y.-L. Ni et al., "Organic contaminants in Chinese sewage sludge: a meta-analysis of the literature of the past 30 years," Environmental Science \& Technology, vol. 50, no. 11, pp. 5454-5466, 2016.

[14] K.-E. Lasaridi, T. Manios, S. Stamatiadis, C. Chroni, and A. Kyriacou, "The evaluation of hazards to man and the environment during the composting of sewage sludge," Sustainability, vol. 10, no. 8, p. 2618, 2018.

[15] K. Fijalkowski, A. Rorat, A. Grobelak, and M. J. Kacprzak, "The presence of contaminations in sewage sludge-the current situation," Journal of Environmental Management, vol. 203, pp. 1126-1136, 2017.

[16] I. Fonts, G. Gea, M. Azuara, J. Ábrego, and J. Arauzo, "Sewage sludge pyrolysis for liquid production: a review," Renewable and Sustainable Energy Reviews, vol. 16, no. 5, pp. 2781-2805, 2012.

[17] A. A. Diatta, J. H. Fike, M. L. Battaglia, J. M. Galbraith, and M. B. Baig, "Effects of biochar on soil fertility and crop productivity in arid regions: a review," Arabian Journal of Geosciences, vol. 13, no. 14, 2020.

[18] M. Hassan, Y. Liu, R. Naidu et al., "Influences of feedstock sources and pyrolysis temperature on the properties of biochar and functionality as adsorbents: a meta-analysis," The Science of the Total Environment, vol. 744, Article ID 140714, 2020.

[19] C. Pituello, O. Francioso, G. Simonetti et al., "Characterization of chemical-physical, structural and morphological properties of biochars from biowastes produced at different temperatures," Journal of Soils and Sediments, vol. 15, no. 4, pp. 792-804, 2014.

[20] Y. Ding, Y. Liu, S. Liu et al., "Biochar to improve soil fertility. A review," Agronomy for Sustainable Development, vol. 36, no. 2, 2016.

[21] H. Yuan, T. Lu, H. Huang, D. Zhao, N. Kobayashi, and Y. Chen, "Influence of pyrolysis temperature on physical and chemical properties of biochar made from sewage sludge," Journal of Analytical and Applied Pyrolysis, vol. 112, pp. 284-289, 2015.

[22] H. Han, S. Hu, S. S. A. Syed-Hassan et al., "Effects of reaction conditions on the emission behaviors of arsenic, cadmium and lead during sewage sludge pyrolysis," Bioresource Technology, vol. 236, pp. 138-145, 2017.

[23] C. E. Brewer, K. Schmidt-Rohr, J. A. Satrio, and R. C. Brown, "Characterization of biochar from fast pyrolysis and gasification systems," Environmental Progress \& Sustainable Energy, vol. 28, no. 3, pp. 386-396, 2009.

[24] S. Cheah, W. S. Jablonski, J. L. Olstad et al., "Effects of thermal pretreatment and catalyst on biomass gasification efficiency and syngas composition," Green Chemistry, vol. 18, no. 23, pp. 6291-6304, 2016.

[25] A. G. Daful and M. R Chandraratne, "Biochar production from biomass waste-derived material," Encyclopedia of Renewable and Sustainable Materials, vol. 4, pp. 370-378, 2020.

[26] Z. Wang, K. Liu, L. Xie et al., "Effects of residence time on characteristics of biochars prepared via co-pyrolysis of sewage sludge and cotton stalks," Journal of Analytical and Applied Pyrolysis, vol. 142, Article ID 104659, 2019.

[27] M. Stefaniuk, P. Oleszczuk, and K. Różyło, "Co-application of sewage sludge with biochar increases disappearance of polycyclic aromatic hydrocarbons from fertilized soil in long term field experiment," The Science of the Total Environment, vol. 599-600, pp. 854-862, 2017.

[28] M. Mierzwa-Hersztek, K. Gondek, A. Klimkowicz-Pawlas, A. Baran, and T. Bajda, "Sewage sludge biochars
management-Ecotoxicity, mobility of heavy metals, and soil microbial biomass," Environmental Toxicology \& Chemistry, vol. 37, no. 4, pp. 1197-1207, 2018.

[29] D. Czajczyńska, T. Nannou, L. Anguilano et al., "Potentials of pyrolysis processes in the waste management sector," Energy Procedia, vol. 123, pp. 387-394, 2017.

[30] D. Urban and M. Antaljr, "Study of the kinetics of sewage sludge pyrolysis using DSC and TGA," Fuel, vol. 61, no. 9, pp. 799-806, 1982.

[31] A. Gonzalo, "Procesado termoquímico de fangos procedentes de estaciones depuradoras de aguas residuales," Doctoral Thesis, Universidad de Zaragoza, Zaragoza, Spain, 2005.

[32] P. Thipkhunthod, V. Meeyoo, P. Rangsunvigit, and T. Rirksomboon, "Describing sewage sludge pyrolysis kinetics by a combination of biomass fractions decomposition," Journal of Analytical and Applied Pyrolysis, vol. 79, no. 1-2, pp. 78-85, 2007.

[33] M. Inguanzo, A. Domínguez, J. A. Menéndez, C. G. Blanco, and J. J. Pis, "On the pyrolysis of sewage sludge: the influence of pyrolysis conditions on solid, liquid and gas fractions," Journal of Analytical and Applied Pyrolysis, vol. 63, no. 1, pp. 209-222, 2002.

[34] Y. Kim and W. Parker, "A technical and economic evaluation of the pyrolysis of sewage sludge for the production of biooil," Bioresource Technology, vol. 99, no. 5, pp. 1409-1416, 2008.

[35] I. Fonts, M. Azuara, G. Gea, and M. B. Murillo, "Study of the pyrolysis liquids obtained from different sewage sludge," Journal of Analytical and Applied Pyrolysis, vol. 85, no. 1-2, pp. 184-191, 2009.

[36] M. Ahmad, A. U. Rajapaksha, J. E. Lim et al., "Biochar as a sorbent for contaminant management in soil and water: a review," Chemosphere, vol. 99, pp. 19-33, 2014.

[37] D. Woldetsadik, P. Drechsel, B. Keraita, B. Marschner, F. Itanna, and H. Gebrekidan, "Effects of biochar and alkaline amendments on cadmium immobilization, selected nutrient and cadmium concentrations of lettuce (Lactuca sativa) in two contrasting soils," Springer Plus, vol. 5, no. 1, pp. 397-416, 2016.

[38] J. Paz-Ferreiro, A. Nieto, A. Méndez, M. Askeland, and G. Gascó, "Biochar from biosolids pyrolysis: a review," International Journal of Environmental Research and Public Health, vol. 15, no. 5, p. 956, 2018.

[39] K. Intani, S. Latif, M. Islam, and J. Müller, "Phytotoxicity of corncob biochar before and after heat treatment and washing," Sustainability, vol. 11, no. 1, p. 30, 2018.

[40] E. S. Penido, G. C. Martins, T. B. M. Mendes, L. C. A. Melo, I. do Rosário Guimarães, and L. R. G. Guilherme, "Combining biochar and sewage sludge for immobilization of heavy metals in mining soils," Ecotoxicology and Environmental Safety, vol. 172, pp. 326-333, 2019.

[41] N. Vali, L.-E. Åmand, A. Combres, T. Richards, and A. Pettersson, "Pyrolysis of municipal sewage sludge to investigate char and phosphorous yield together with heavymetal removal-experimental and by thermodynamic calculations," Energies, vol. 14, no. 5, p. 1477, 2021.

[42] G. Li, G. X. Sun, Y. Ren, X. S. Luo, and Y. G. Zhu, "Urban soil and human health: a review," European Journal of Soil Science, vol. 69, no. 1, pp. 196-215, 2018.

[43] G. Yang, J. Roy, S. D. Veresoglou, and M. C. Rillig, "Soil biodiversity enhances the persistence of legumes under climate change," New Phytologist, vol. 229, no. 5, pp. 2945-2956, 2020. 
[44] E. N. Yargicoglu, B. Y. Sadasivam, K. R. Reddy, and K. Spokas, "Physical and chemical characterization of waste wood derived biochars," Waste Management, vol. 36, pp. 256-268, 2015.

[45] H. Blanco-Canqui, "Biochar and soil physical properties," Soil Science Society of America Journal, vol. 81, no. 4, pp. 687-711, 2017.

[46] E. F. Zama, Y.-G. Zhu, B. J. Reid, and G.-X. Sun, “The role of biochar properties in influencing the sorption and desorption of $\mathrm{Pb}$ (ii), $\mathrm{Cd}(\mathrm{ii})$ and $\mathrm{As}(\mathrm{iii})$ in aqueous solution," Journal of Cleaner Production, vol. 148, pp. 127-136, 2017.

[47] S.-X. Zhao, N. Ta, and X.-D. Wang, "Effect of temperature on the structural and physicochemical properties of biochar with apple tree branches as feedstock material," Energies, vol. 10, no. 9, p. 1293, 2017.

[48] P. Oleszczuk, A. Malara, I. Jośko, and A. Lesiuk, "The phytotoxicity changes of sewage sludge-amended soils," Water, Air, \& Soil Pollution, vol. 223, no. 8, pp. 4937-4948, 2012.

[49] A. Priac, P.-M. Badot, and G. Crini, "Treated wastewater phytotoxicity assessment using Lactuca sativa: focus on germination and root elongation test parameters," Comptes Rendus Biologies, vol. 340, no. 3, pp. 188-194, 2017.

[50] A. Lešková, M. Zvarík, T. Araya, and R. F. H. Giehl, "Nickel toxicity targets cell wall-related processes and PIN2-mediated auxin transport to inhibit root elongation and gravitropic responses in arabidopsis," Plant and Cell Physiology, vol. 61, no. 3, pp. 519-535, 2019.

[51] R. I. Zoghlami, H. Hamdi, K. Boudabbous, S. Hechmi, M. N. Khelil, and N. Jedidi, "Seasonal toxicity variation in light-textured soil amended with urban sewage sludge: interaction effect on cadmium, nickel, and phytotoxicity," Environmental Science and Pollution Research, vol. 25, no. 4, pp. 3608-3615, 2017.

[52] J. Costa e Silva, B. M. Potts, A. R. Gilmour, and R. J. Kerr, "Genetic-based interactions among tree neighbors: identification of the most influential neighbors, and estimation of correlations among direct and indirect genetic effects for leaf disease and growth in Eucalyptus globulus," Heredity, vol. 119, no. 3, pp. 125-135, 2017.

[53] K. Phoungthong, H. Zhang, L.-M. Shao, and P.-J. He, "Leaching characteristics and phytotoxic effects of sewage sludge biochar," Journal of Material Cycles and Waste Management, vol. 20, no. 4, pp. 2089-2099, 2018.

[54] S. Lacorte, F. Bono-Blay, and M. Cortina-Puig, "Sample homogenization," in Comprehensive Sampling and Sample Preparation, J. Pawliszyn and J. M. Bayona, Eds., pp. 65-84, Elsevier, Amsterdam, Netherlands, 2012.

[55] I. Y. Mohammed, Y. A. Abakr, F. K. Kazi, S. Yusuf, I. Alshareef, and S. A. Chin, "Pyrolysis of napier grass in a fixed bed reactor: effect of operating conditions on product yields and characteristics," BioResources, vol. 10, no. 4, pp. 6457-6478, 2015.

[56] Z. Ye, L. Liu, Z. Tan, L. Zhang, and Q. Huang, "Effects of pyrolysis conditions on migration and distribution of biochar nitrogen in the soil-plant-atmosphere system," The Science of the Total Environment, vol. 723, Article ID 138006, 2020.

[57] S. K. Yong, A. K. Wood, and A. R. Ahmad, Laboratory Manual for Soil Science and Analysis, UiTM Press, Selangor, Malaysia, 2015.

[58] J. M. Bremnen, "Nitrogen-total," in Methods of soil analysis, D. L. Sparks, Ed., vol. 3, pp. 1085-1111, SSA, Madison, WI, USA, 1996.

[59] ISO 6491, Animal Feeding Stuffs: Determination of Phosphorus Content: Spectrometric Method, International Organization for Standardization, Geneva, Switzerland, 1998, https://www. iso.org/obp/ui/\#iso:std:iso:6491:ed-2:v1:en.

[60] ISO 6869, Animal Feeding Stuffs: Determination of the Contents of Calcium, Copper, Iron, Magnesium, Man-Ganese, Potassium, Sodium and Zinc: Method Using Atomic Absorption Spectrometry, International Organization for Standardization, Geneva, Switzerland, 2000, https://www.iso.org/obp/ ui/\#iso:std:iso:6869:ed-1:v1:en.

[61] Y. Lu, H. Yao, D. Shan, Y. Jiang, S. Zhang, and J. Yang, "Heavy metal residues in soil and accumulation in maize at long-term wastewater irrigation area in tongliao, China," Journal of Chemistry, vol. 2015, Article ID 628280, 9 pages, 2015.

[62] A. Tomczyk, Z. Sokołowska, and P. Boguta, "Biochar physicochemical properties: pyrolysis temperature and feedstock kind effects," Reviews in Environmental Science and Biotechnology, vol. 19, no. 1, pp. 191-215, 2020.

[63] A. T. Tag, G. Duman, S. Ucar, and J. Yanik, "Effects of feedstock type and pyrolysis temperature on potential applications of biochar," Journal of Analytical and Applied Pyrolysis, vol. 120, pp. 200-206, 2016.

[64] F. Yang, X.-q. Lee, and B. Wang, "Characterization of biochars produced from seven biomasses grown in three different climate zones," Chinese Journal of Geochemistry, vol. 34, no. 4, pp. 592-600, 2015.

[65] W. Kajina and P. Rousset, "Coupled effect of feedstock and pyrolysis temperature on biochar as a soil amendment," in Proceedings of Interdisciplinary research enhancement for industrial revolution 4.0, Belintung, Indonésie, August 2018.

[66] D. E. Carey, P. J. McNamara, and D. H. Zitomer, "Biochar from pyrolysis of biosolids for nutrient adsorption and turfgrass cultivation," Water Environment Research, vol. 87, no. 12, pp. 2098-2106, 2015.

[67] N. Saffari, M. A. Hajabbasi, H. Shirani, M. R. Mosaddeghi, and A. I. Mamedov, "Biochar type and pyrolysis temperature effects on soil quality indicators and structural stability," Journal of Environmental Management, vol. 261, Article ID 110190, 2020.

[68] T. Liu, Y. Guo, N. Peng et al., "Nitrogen transformation among char, tar and gas during pyrolysis of sewage sludge and corresponding hydrochar," Journal of Analytical and Applied Pyrolysis, vol. 126, pp. 298-306, 2017.

[69] R. Shi, X. Zhang, G. I. N. Waterhouse, Y. Zhao, and T. Zhang, "The journey toward low temperature, low pressure catalytic nitrogen fixation," Advanced Energy Materials, vol. 10, no. 19, Article ID 2000659, 2020.

[70] G. E. Brust, "Management strategies for organic vegetable fertility," Safety and Practice for Organic Food, Academic Press, Cambridge, MA, USA, pp. 193-212, 2019.

[71] S. Wei, M. Zhu, X. Fan et al., "Influence of pyrolysis temperature and feedstock on carbon fractions of biochar produced from pyrolysis of rice straw, pine wood, pig manure and sewage sludge," Chemosphere, vol. 218, pp. 624-631, 2019.

[72] D. M. Sylvia, "Biological control of soilborne plant pathogens and nematodes," in Principles and Applications of Soil Microbiology, vol. 564-565, pp. 633-635, Pearson Education, Upper Saddle River, NJ, USA, 2005.

[73] J. M. Novak, W. J. Busscher, D. L. Laird, M. Ahmedna, D. W. Watts, and M. A. S. Niandou, "Impact of biochar amendment on fertility of a southeastern coastal plain soil," Soil Science, vol. 174, no. 2, pp. 105-112, 2009.

[74] T.-T. Qian and H. Jiang, "Migration of phosphorus in sewage sludge during different thermal treatment processes," ACS Sustainable Chemistry \& Engineering, vol. 2, no. 6, pp. 14111419, 2014. 
[75] L. Dai, H. Li, F. Tan, N. Zhu, M. He, and G. Hu, "Biochar: a potential route for recycling of phosphorus in agricultural residues," GCB Bioenergy, vol. 8, no. 5, pp. 852-858, 2016.

[76] X. Sun, X. Han, F. Ping et al., "Effect of rice-straw biochar on nitrous oxide emissions from paddy soils under elevated $\mathrm{CO} 2$ and temperature," The Science of the Total Environment, vol. 628-629, pp. 1009-1016, 2018.

[77] B. Glaser and V.-I. Lehr, "Biochar effects on phosphorus availability in agricultural soils: a meta-analysis," Scientific Reports, vol. 9, no. 1, p. 9338, 2019.

[78] R. Chintala, T. E. Schumacher, L. M. McDonald et al., "Phosphorus sorption and availability from biochars and soil/ biochar mixtures," Clean-Soil, Air, Water, vol. 42, no. 5, pp. 626-634, 2013.

[79] T. Chen, Y. Zhang, H. Wang et al., "Influence of pyrolysis temperature on characteristics and heavy metal adsorptive performance of biochar derived from municipal sewage sludge," Bioresource Technology, vol. 164, pp. 47-54, 2014.

[80] A. Zielińska, P. Oleszczuk, B. Charmas, J. SkubiszewskaZięba, and S. Pasieczna-Patkowska, "Effect of sewage sludges properties on the biochar characteristic," Journal of Analytical and Applied Pyrolysis, vol. 112, pp. 201-213, 2015.

[81] M. A.-A. Baquy, J.-Y. Li, C.-Y. Xu, K. Mehmood, and R.-K. Xu, "Determination of critical $\mathrm{pH}$ and $\mathrm{Al}$ concentration of acidic Ultisols for wheat and canola crops," Solid Earth, vol. 8, no. 1, pp. 149-159, 2017.

[82] H. Yu, Z. Zhang, Z. Li, and D. Chen, "Characteristic of tar formation during cellulose, hemicellulose and lignin gasification," Fuel, vol. 118, pp. 25-256, 2014.

[83] W. Ding, X. Dong, I. M. Ime, B. Gao, and L. Q. Ma, "Pyrolytic temperatures impact lead sorption mechanisms by bagasse biochars," Chemosphere, vol. 105, pp. 68-74, 2014.

[84] M. I. Al-Wabel, M. I. Rafique, M. Ahmad, M. Ahmad, A. Hussain, and A. R. A. Usman, "Pyrolytic and hydrothermal carbonization of date palm leaflets: characteristics and ecotoxicological effects on seed germination of lettuce," Saudi Journal of Biological Sciences, vol. 26, no. 4, pp. 665-672, 2019.

[85] M. Laghari, M. S. Mirjat, Z. Hu et al., "Effects of biochar application rate on sandy desert soil properties and sorghum growth," Catena, vol. 135, pp. 313-320, 2015.

[86] E. J. Foster, N. Hansen, M. Wallenstein, and M. F. Cotrufo, "Biochar and manure amendments impact soil nutrients and microbial enzymatic activities in a semi-arid irrigated maize cropping system," Agriculture, Ecosystems \& Environment, vol. 233, pp. 404-414, 2016.

[87] S. Jeffery, D. Abalos, M. Prodana et al., "Biochar boosts tropical but not temperate crop yields," Environmental Research Letters, vol. 12, no. 5, Article ID 053001, 2017.

[88] R. I. Zoghlami, H. Hamdi, S. Mokni-Tlili et al., "Monitoring the variation of soil quality with sewage sludge application rates in absence of rhizosphere effect," International soil and water conservation research, vol. 8, no. 3, pp. 245-252, 2020.

[89] H. Oueriemmi, P. Kidd, C. Trasar-Cepeda et al., "Evaluation of composted organic wastes and farmyard manure for improving fertility of poor sandy soils in arid regions," Agriculture, vol. 11, no. 5, p. 415, 2021.

[90] S. M. Ndirangu, Y. Liu, K. Xu, and S. Song, "Risk evaluation of pyrolyzed biochar from multiple wastes," Journal of Chemistry, vol. 2019, Article ID 4506314, 28 pages, 2019.

[91] E. Mancinelli, E. Baltrènaitè, P. Baltrènas, E. Marčiulaitienè, and G. Passerini, "Dissolved organic carbon content and leachability of biomass waste biochar for trace metal $(\mathrm{Cd}, \mathrm{Cu}$ and $\mathrm{Pb}$ ) speciation modelling," Journal of Environmental
Engineering and Landscape Management, vol. 25, no. 4, pp. 354-366, 2017.

[92] A. Méndez, A. Gómez, J. Paz-Ferreiro, and G. Gascó, "Effects of sewage sludge biochar on plant metal availability after application to a Mediterranean soil," Chemosphere, vol. 89, no. 11, pp. 1354-1359, 2012.

[93] EBC, European Biochar Certificate-Guidelines for a Sustainable Production of Biochar, European Biochar Foundation (EBC), Arbaz, Switzerland, 2012. 